\title{
$\mathrm{Au}$ 抗原感作血球調製に打ける感作方法の比較検討
}

\author{
滝 本 義 一 \\ （エーザイ株式会社研究所）
}

（受付 : 昭和 49 年 1 月 8 日）

\section{THE COMPARISON OF THE SENSITIZATION PROCEDURES \\ FOR THE ATTACHMENT OF AU ANTIGEN TO \\ ERYTHROCYTES}

by

Giichi Tакімото

(Research Laboratories, Eisai Co., Ltd.)

Eight modifications of hemagglutination technique were applied to the sensitization of sheep erythrocytes with Au antigen; these included tannic acid (TA ${ }^{1)}$, bis-diazotized benzidine $(\mathrm{BDB})^{2)}$, tolylene - 2,4 - diisocyanate $(\mathrm{TDIC})^{3)}$, difluorodinitrobenzene ${ }^{4)}$, tetraazotized O-dianisidine (TOD) ${ }^{5}$, cyanulic chloride ${ }^{5}$, glutaraldehyde ${ }^{6)}$ and chromic chloride $\left(\mathrm{CrCl}_{3}\right)^{7)}$ method.

The sensitized cells could be obtained only using TA, BDB, TDIC or TOD in the glutaraldehyde-treated cells and $\mathrm{CrCl}_{3}$ in the native cells, if the concentration of $\mathrm{Au}$ antigen in the reaction solution was limited to about $25 \mathrm{\gamma} / \mathrm{m} l$. Among these reagents the best result was obtained with BDB.

The coupling of $\mathrm{Au}$ antigen to erythrocytes with these reagents seems not significantly to inactivate the antigenic groups of $\mathrm{Au}$ antigen.

The cells coated with the aid of BDB, TDIC or TA could be used again without any appreciable loss of hemagglutination titer for 4 months when preserved at $4^{\circ} \mathrm{C}$.

\section{References}

1) Imai, M., et al.: Igaku no Ayumi 78: 759-760, 1971.

2) Herbert, W.J.: Handbook of Immunology (Ed. by P.M. Weir), Blackwell Scientific Publication, Oxford, 1967, P. 720-744.

3) Gyenes, L., et al.: Immunochemistry, 1: 43-48, 1964.

4) Ling, N.R.: Immunology, 4: 49-54, 1961.

5) Avrameas, S., et al.: Immunochemistry, 6: 6776, 1969.

6) Onkelinx, E., et al.: Immunology, 16: 35-43, 1969.

7) Vyas, G.N., et al.: Science, 170: 332-333, 1970.

\section{はじめに}

受身赤血球凝集反応法は, 極めて感度よく抗体 を検出する方法として知られているが，その抗体 検出感度は感作血球の品質により大きく影響され る. 感作血球の調製法としては，一般にタンニン 酸法 ( T A 法 $)^{1)}$ 打よび Bis-diazotized benzidine
法 (B D B 法)2)がよく用いられているが，その他 に, Tolylene-2,4-diisocyanate 法 ( T D I C 法) ${ }^{3}$, 1,3-difluoro-4,6-dinitrobenzene 法 (DFDNB 法)4), Glutaraldehyde 法 (G A 法) ${ }^{5-7}$, Cyanulic chloride 法 $(\mathrm{CyCl} \text { 法 })^{7}$, Tetraazotized O-dianisidine 法 ( T O D 法) ${ }^{7}$ ), 1-Ethyl-3 - (3-dimethylamino- 
propyl) carbodiimide 法 (E C D I 法 $)^{8)}$, Chromic chloride 法 $\left(\mathrm{CrCl}_{3} \text { 法 }\right)^{9)}$, などが知られている. そして, 各感作方法の感作成績は感作抗原の種類 によって大きく変わることがあり，したがって， どの感作法が優れているかを一概に論ずることは できない，B型肝炎との関連において大きな注目 を浴びているオーストラリア抗原（Au 抗原）に ついては，グルタールアルデヒド固定ヒツジ赤血 球に T A 法を応用した報告 ${ }^{10)}$ ，牧よびヒト O 型生 赤血球に $\mathrm{CrCl}_{3}$ 法を応用した報告 ${ }^{11)}$ がある.この 報告では，ヒッジ生血球および固定血球を用いて 前記の各種感作法を応用し，その感作成績を比較 した.

\section{実験材料と方法}

1）七ツジ赤血球：前報 ${ }^{12)}$ とよると, 感作血球の品質 は感作に使用する血球のロットによってかなりの差を生 ずる. そのため感作法の比較実験では, 使用血球の条件 をなるべく同等にすることが必要である. 今回の実験で は，固定血球は，すべて同一ロットを使用し，生血球は 同一ロットではないが採血 7 日目の血球を用いた.

2）血球の固定法：今井らの報告 ${ }^{10}$ 亿準拠した。すな わち, 採血 7 日目のヒツジ赤血球を, 生理食塩水で 3 回 洗浄したのち，比色法 ${ }^{13)}$ にり $5 \%$ 血球液を調製した. つぎに市販のグルタールアルデヒド液 $(24-26 \%) を 10$ 倍希釈 (希釈液は, $0.15 \mathrm{M}$ リン酸緩衝液 $(\mathrm{pH} 7.2$ ) と生理 食塩水の等容混合液：P B S と略）したのち, 血球液の $1 / 5$ 相当量を添加して，室温，60分間擋拌した. つぎに， 生理食塩水で 4 回洗浄したのち, 前記 P B S に恶濁して $5 \%$ 血球液として保存した.

3）感作用 $\mathrm{Au}$ 抗原：Gerin らの報告 ${ }^{14)}$ 亿準拠して, 高度精製したものを用いた。ここの精製 $\mathrm{Au}$ 抗原液は原液 の $\mathrm{OD}_{280}=3.0$ (約 $1 \mathrm{mg} / \mathrm{m} l$ ) 飞打いて一元免度払散法 でヒト血清成分を検出しなかった。なお，感作時には， 原液の 20 倍希釈液（約 $50 \mathrm{r} / \mathrm{m} l$ ) を用いた.

4） T A 法: 今井らの報告 ${ }^{10)}$ に準拠して以下のように 実施した. $5 \%$ 血球液 $1.5 \mathrm{~m} l$ (P B S ) とタンニン酸液 （ 2.5 20mg/ $100 \mathrm{ml}, \mathrm{PBS}) 1.5 \mathrm{ml}$ を混合し, $37^{\circ} \mathrm{C}$, 15分間擋拌したのち, 生理食塩水で 1 回洗浄した。つぎ 飞, $2.5 \%$ タンニン酸処理血球液 $3.0 \mathrm{ml}$ と $\mathrm{Au}$ 抗原液 $3.0 \mathrm{ml}$ を混合し，室温，30分間擋拌したのち，P B S で 3 回洗浄し, 最後に, $2 \%$ 正常ウサギ血清含有 P B S K 懸濁し $1 \%$ 血球濃度として 使用した。な拈正常ウサギ
血清は，あらかじめ固定ヒッジ血球で吸収処理したもの （N R S と略）を用いた.

5） B D B 法：Herbert の報告 ${ }^{15)}$ 飞準拠して以下のよ うに実施した. $2.5 \%$ 血球液 $1.5 \mathrm{~m} l$ ( P B S ) と $\mathrm{Au}$ 抗原 液 $1.5 \mathrm{~m} l$ の混合液にあらかじめ調製しておいた B D B 液（原液の $3.5 \sim 10$ 倍希釈液, $\mathrm{P} \mathrm{B} \mathrm{S} \mathrm{)} 0.5 \mathrm{~m} l$ を加兄 $\tau, 37^{\circ} \mathrm{C}, 15$ 分間摚拌した. 感作後, $0.5 \% \mathrm{~N} \mathrm{R} \mathrm{S}$ 含有 P B S で 3 回洗浄し, 最後に, $2 \%$ N R S 含有P B S 懸濁して $1 \%$ 血球濃度として使用した.

6） T D I C 法 : Gyenes らの報告3) に準拠 し以下の ように実施した. $2.5 \%$ 血球液 $1.5 \mathrm{~m} l$ (生理食塩水) 之 $\mathrm{Au}$ 抗原液 (生理食塩水) $1.5 \mathrm{~m} l$ の混合液に, 各種 濃度の T D I C 液 $(0.02 \sim 0.10 \mathrm{~g} / 10 \mathrm{~m} l$, dioxane) $0.2 \mathrm{ml}$ をくわ兄て, 室温, 30 分間擋拌する. $0.5 \%$ N R S 含有 P B S で 3 回洗浄したのち, $2 \%$ N R S 含有 P B S に 懸濁して $1 \%$ 血球濃度として使用した.

7） DFDNB 法：Ling の報告) に準拠 して以下のよ うに実施した. $10 \%$ 濃度血球液 $0.5 \mathrm{~m} l$ (EDTA 緩衝液, $\mathrm{pH} 8.4)$, 各種濃度の DFDNB 液 $(0.01 \sim 0.08 \mathrm{~g} / \mathrm{ml}$, EDTA 緩衝液pH 8.4） $0.015 \mathrm{ml}$, 拈よびE D T A 緩衝液 （pH 8.4） $1.0 \mathrm{~m} l$ とを混合し, $37^{\circ} \mathrm{C}, 30$ 分間擋拌した. 同緩衝液で 1 回洗浄後, 同液にて $2.5 \%$ 血球液とした。 処理血球液 $1.5 \mathrm{~m} l$ と $\mathrm{Au}$ 抗原液 $1.5 \mathrm{~m} l$ とを混合し, $37^{\circ} \mathrm{C}, 60$ 分間擋拌した. E D T A 緩衝液( $\mathrm{pH} 7.5$ )で 3 回

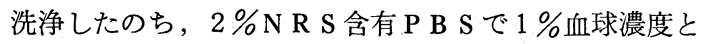
し使用した。

8） G A 法：Onkelinx らの報告5) 飞準拠して以下の ように実施した． $2.5 \%$ 血球液 $1.5 \mathrm{ml}$ (PBS) と, $\mathrm{Au}$ 抗原液 $1.5 \mathrm{~m} l$ (PBS) の混合液に, 各種濃度の G.A 液 $(0.25 \sim 10 \%$, P B S ) を加えて, 室温, 60分間擋拌を 扣こない，生理食塩水で 4 回洗浄後， $2 \% \mathrm{NRS}$ 含有 P B S Kて 1\%血球濃度とし使用した.

9） T OD法：Avrameas ·の報告7) 飞準拠して以下 のように実施した． $5 \%$ 血球液 $0.75 \mathrm{ml}$ (PBS) と, $\mathrm{Au}$ 抗原液 $1.5 \mathrm{ml}(\mathrm{PBS})$ の 混合液飞各種濃度の T OD液 $(0.03 \sim 1 \mathrm{mg} / \mathrm{ml}, 0.15 \mathrm{MKCl}$ 液） $0.3 \mathrm{ml}$ を加兄，室 温，40分間擋拌した.PB Sで 3 回洗浄後， $2 \% \mathrm{NR} \mathrm{S}$ 含有 P B S にて $1 \%$ 血球濃度とし使用した.

10） $\mathrm{CyCl}$ 法: Avrameas らの報告》 飞準拠して以下 のように実施した. $5 \%$ 血球液 $0.75 \mathrm{~m} l$ (PBS) と, $\mathrm{Au}$ 抗原液 $1.5 \mathrm{~m} l$ (PBS) の混合液に各種濃度の $\mathrm{CyCl}$ 液 ( $0.031 \sim 1 \mathrm{mg} / \mathrm{ml}$, acetone) $0.5 \mathrm{ml}$ を加光, 室温, 30分擋拌した. P B S で 3 回洗浄後， $2 \% \mathrm{NR} \mathrm{S}$ 含有 
P B S にて 1\%血球濃度とし使用した.

11) $\mathrm{CrCl}_{3}$ 法: Vyas らの報告 ${ }^{11}$ に準拠して以下のよ らに実施した。 $2.5 \%$ 血球液 $1.5 \mathrm{ml}$ （生理食塩水）と $\mathrm{Au}$ 抗原液 $1.5 \mathrm{~m} l$ (生理食塩水) の混合液に, 各種濃度 の $\mathrm{CrCl}_{3}$ 液 $(1.0 \sim 10.0 \mathrm{mM}$, 生理食塩水) $0.5 \mathrm{ml}$ を加 え, 室温, 30分間撹拌した. 生理食塩水で 4 回洗浄した のち， $2 \% \mathrm{~N} \mathrm{R} \mathrm{S}$ 含有 P B S てて $1 \%$ 血球濃度とし使用 した.

12）感作血球の検定：Microtitration 法 $^{16)}$ によった. 実施詳細は前報 ${ }^{12)}$ に記載した.

$\mathrm{Au}$ 抗原の抗原決定基に対する特異抗体は，自治医大 $\mathrm{Au}$ 抗原グループより分与を受けた.

\section{実験結果}

感作血球の血球凝集価や凝集像は，感作処理を おこならときの感作抗原の質や濃度，および結合 剂の濃度に大いに影響される，そのため，感作法

表 1 T A 法による感作成績

\begin{tabular}{|c|c|c|c|c|}
\hline \multirow{2}{*}{$\mathrm{T} \cdot \mathrm{A}$ 濃度 } & \multicolumn{2}{|c|}{ 血球凝集価 } & \multirow{2}{*}{ 㓌性像 } & \multirow{2}{*}{ 備考 } \\
\hline & $\mathrm{F}$ & N-357 & & \\
\hline $20 \mathrm{mg} / 100 \mathrm{ml}$ & 200 & 0 & A & \\
\hline 10 & 200 & 0 & A & \\
\hline 5 & 200 & 0 & $\mathrm{~A}$ & 陽性像弱い \\
\hline 2.5 & 200 & 0 & A & " \\
\hline
\end{tabular}

* 旡性像は, 鮮明さにもとづき A, B , C, Dの 4 段階に分けた。Aが最も鮮明とし，Dが最も 不鮮明として，その中間像を B，Cとした。

の比較は, 同一ロットの精製 $\mathrm{Au}$ 抗原のほぼ同一 濃度（最終濃度約 $25 \gamma / \mathrm{ml}$ )を感作抗原とし， 結合 剂の濃度を種々に変えておこなった，感作成績の 結果についておこなった。感作成績は，おもに， 七十由来の抗 $\mathrm{Au}$ 陽性血清 “ $\mathrm{F}$ ” の示す血球凝集 価，ヒト由来の抗 $\mathrm{Au}$ 陰性血清 “N $\mathrm{N}-357 ”$ の示す 抗 $\mathrm{Au}$ によらない血球凝集価，ならびに凝集陰性 像の鮮明さなどについて評価した。

1) 固定血球を用いた場合の感作方法の比較 実施した 8 種類の感作法のらち被検条件におい て感作できたのは，T A法， B D B法，T D I C 法 T O D法の 4 種であった。 それらの感作成績を （表 1) 〜 (表 4) にてしめす. これらのらち, 最 も感作成績の優れていたのは B D B 法であった.
表 2 B D B 法による感作成績

\begin{tabular}{|c|c|c|c|}
\hline \multirow{2}{*}{$\begin{array}{l}\text { B D B 濃度 } \\
\left(\begin{array}{c}\text { 原液 } \\
\text { 希釈倍数 }\end{array}\right)\end{array}$} & \multicolumn{2}{|c|}{ 血球凝集価 } & \multirow{2}{*}{ 院性像 } \\
\hline & $\mathrm{F}$ & $\mathrm{N}-357$ & \\
\hline $3.5 \times$ & N.S.A* & N.S.A & $\mathrm{D}$ \\
\hline 5 & 1600 & 2 & A \\
\hline 7.5 & 800 & 2 & $\mathrm{~A}$ \\
\hline 10 & 800 & 0 & A \\
\hline
\end{tabular}

* 抗 $\mathrm{Au}$ 抗体によらない非特異的凝集

表 3 T D I C 法による感作成績

\begin{tabular}{l|r|r|c}
\hline \multirow{2}{*}{ T D I C 濃度 } & \multicolumn{2}{|c|}{ 血球凝集価 } & \multirow{2}{*}{ 陰性像 } \\
\cline { 2 - 3 } & F & N-357 & \\
\hline $0.10 \mathrm{~g} / 10 \mathrm{~m} l$ & 400 & 8 & $\mathrm{C}$ \\
0.08 & 800 & 8 & $\mathrm{C}$ \\
0.06 & 800 & 8 & B \\
0.04 & 0 & 4 & B \\
0.02 & 0 & 4 & A \\
\hline
\end{tabular}

表 4 T O D 法による感作成績

\begin{tabular}{l|c|c|c}
\hline \multirow{2}{*}{ T O D濃度 } & \multicolumn{2}{|c|}{ 血球凝集価 } & \multirow{2}{*}{ 陰性像 } \\
\cline { 2 - 3 } & $\mathrm{F}$ & $\mathrm{N}-357$ & \\
\hline $1 \mathrm{mg} / \mathrm{m} l$ & 50 & 2 & $\mathrm{~B}$ \\
0.5 & 0 & 2 & $\mathrm{~A}$ \\
0.25 & 0 & 2 & $\mathrm{~A}$ \\
0.125 & 0 & 2 & $\mathrm{~A}$ \\
0.6 & 0 & 2 & $\mathrm{~A}$ \\
0.3 & 0 & 2 & $\mathrm{~A}$ \\
\hline
\end{tabular}

表 $5 \mathrm{CrCl}_{3}$ 法による感作成績

\begin{tabular}{c|c|c|c}
\hline \multirow{2}{*}{$\mathrm{CrCl}_{3}$ 濃度 } & \multicolumn{2}{|c|}{ 血球凝集価 } & \multirow{2}{*}{ 陰性像 } \\
\cline { 2 - 3 } & $\mathrm{F}$ & $\mathrm{N}-357$ & \\
\hline $10 \mathrm{mM}$ & 0 & 2 & $\mathrm{~A}$ \\
7.5 & 0 & 2 & $\mathrm{~A}$ \\
5.0 & 0 & 2 & $\mathrm{~A}$ \\
2.5 & 1600 & 8 & $\mathrm{C}$ \\
1.0 & 1600 & 4 & $\mathrm{~B}$ \\
0.5 & 800 & 2 & $\mathrm{~A}$ \\
\hline
\end{tabular}

すなわち B D B 濃度 $3.5 \times$ (原液より希釈倍数) では非特異凝集のため凝集の判定が不可能であっ たが， $5 \times$ では “F”に対する血球凝集価が被検 
条件中で最も高く, 一方, N-357 の示す非特異的 凝集性は低く, 陰性像も鮮明であった。 T D I C 法は，T D I C濃度 $0.06 \sim 0.10 \mathrm{~g} / 10 \mathrm{ml}$ に打いて Fに対する見かけ上の血球凝集価が高かったが， しかし，N-357 に対する非特異的凝集性や陰性像 の鮮明さにおいて著るしく劣っていた，T A 法 は，被検 $\mathrm{T} \mathrm{A}$ 濃度の範囲に敃いて $\mathrm{F}$ の血球凝集価 に差がみられず，そしていずれの条件にても血球 凝集価は比較的低かった。 しかし，N-357 に対す る非特異凝集性が全くなく，陰性像も鮮明であっ た. TOD法は, 前述の 3 つの方法にくらべて, 感作成績は著しく悪かった，その他の 4 方法は, 抗 $\mathrm{Au}$ 抗血清に対して特異的凝集性を示さなかっ た.

2）生血球を用いた場合の感作成績の比較

8 種類の感作法のうち被検条件において感作が 成功したのは $\mathrm{CrCl}_{3}$ 法のみであった. その成績 を表 5 と示す結果より, $\mathrm{CrCl}_{3}$ 濃度 $1.0 \sim 2.5 \mathrm{mM}$ で感作した血球は血球凝集価が高く，固定血球 の場合の B D B法に匹適した。しかし，N-357の 非特異凝集性や陰性像の鮮明さに沶いて, やや悪 かった，その他の方法では，条件によって し $2 \sim 16 \times$ の血球凝集価を示す場合があったが, これらの凝集は精製 $\mathrm{Au}$ 抗原 (約 $10 \gamma / \mathrm{m} l$ 濃度)に よる凝集阻止を全く受けなかった。 また，生血球 では, 感作処理中に溶血が沶こる場合が多く,

B D B 法， DFDNB 法， CyCl 法にその傾向が著 しかった.

3） $\mathrm{Au}$ 抗原の抗原決定基への影響

$\mathrm{Au}$ 抗原には，いくつかの抗原決定基が知られ ているが ${ }^{17,18)}$ ，感作方法によってはこれらの抗原 決定基が失活される可能性がある，この点を確認 する為, T A法, B D B法, $\mathrm{CrCl}_{3}$ 法, T D I C 法によって調製した感作血球について, 各抗原 決定基の特異抗体にたいする血球凝集価を比較し た. 表 6 の結果より，いずれの感作血球において も，ある特異抗体の血球凝集価が著しく低下寸る ことは認められなかった. しかし, 抗 $\mathrm{Au}$ 抗血清 F打よび S に対し高い血球凝集性を示す T D I C 感作血球は，他の方法にくらべて, Anti-R,
Anti-S ${ }_{2}$, Anti-Osに対する血球凝集価が低い傾向が あり, 特に Anti-Os に著しかった. また，B D B 感作血球の $\mathrm{F}$ および $\mathrm{S}$ に対する血球凝集価は，他

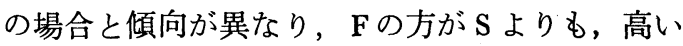
凝集価を与えた。

4）感作血球の保存性

各感作法によって調製した感作血球を $4{ }^{\circ} \mathrm{C}$ 冷蔵 庫に 4 カ月保存したのちの血球凝集価を調べた。 表 7 の結果より，BＤＢ法，およびT D I C 法の

表 $6 \mathrm{Au}$ 抗原の抗原决定基への影響

\begin{tabular}{c|c|c|c|c}
\hline \multirow{2}{*}{ 被検抗体 } & \multicolumn{4}{|c}{ 感作方法 } \\
\cline { 2 - 5 } & T A 法 & BDB法 & TDIC 法 & CrCl $_{3}$ 法 \\
\hline $\mathrm{F}$ & $7 / 4$ & $8 / 3$ & $8 / 2$ & $6 / 2$ \\
$\mathrm{~S}$ & $8 / 4$ & $7 / 3$ & $9 / 2$ & $7 / 3$ \\
Anti-R & $5 / 1$ & $5 / 0$ & $4 / 0$ & $4 / 0$ \\
Anti-S $_{1}$ & $7 / 3$ & $6 / 2$ & $6 / 2$ & $5 / 2$ \\
Anti-S $_{2}$ & $6 / 2$ & $5 / 0$ & $4 / 0$ & $3 / 0$ \\
Anti-S & $7 / 3$ & $6 / 1$ & $7 / 1$ & $5 / 2$ \\
Anti-Os & $7 / 3$ & $6 / 1$ & $4 / 2$ & $6 / 2$ \\
\hline
\end{tabular}

表中の数值は被検抗体の 2 倍希釈系列において 凝集を認めた最終希釈管数を示し，そして，凝集 阻止用 $\mathrm{Au}$ 抗原（精製 $\mathrm{Au}$ 約 $10 \gamma / \mathrm{ml}$ ) を加えない 場合と加えた場合の結果が対になつている。

表 7 感作血球の保存性

\begin{tabular}{l|c|c}
\hline \multirow{2}{*}{ 感作方法 } & \multicolumn{2}{|c}{ F に対する血球凝集価 } \\
\cline { 2 - 3 } & 調製直後 & 4 力後 \\
\hline TA 法 & 200 & 200 \\
BDB 法 & 1600 & 1600 \\
TDIC 法 & 1600 & 1600 \\
$\mathrm{CrCl}_{3}$ 法 & 1600 & 800 \\
\hline
\end{tabular}

感作血球は，全く血球凝集価の 低下がみられな かった. T A 感作血球は使用直前 1 回洗浄操作を おこならと, 調製直後と全く変らない血球凝集価 が得られた. $\mathrm{CrCl}_{3}$ 感作血球は，保存中に相当な 溶血があったが，やはり使用直前に 1 回洗浄した のち， $1 \%$ 血球濃度に再調製し使用すると，わず かに 1 管の力価低下を認めたにすぎなかった.

\section{考案}

タンパク質を感作抗原とする感作血球調製法 


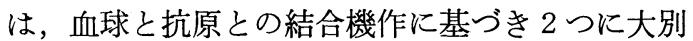
される１つは単なる吸着による場合で，T A法 および $\mathrm{CrCl}_{8}$ 法がこれに属する．他は血球の表面 物質と抗原とが，化学的共有結合で結ばれる場合 で, B D B法, T D I C法, G A法, DFDNB 法 $\mathrm{CyCl}$ 法， T OD法，などがこれに属すると考兄 られる.これらの感作法による感作成績は, 感作 抗原の種類や感作時の抗原濃度などに大きく左右 されることがわかっており，ぞの感作法が優れて いるかを一概に論ずることはできない．この報告 では，過去の文献に記載のあった感作法のうち， 8 種類の方法について, 文献記載の至適条件付近 の条件を用いて Au 感作血球の調製を試みた。 た だし，抗原濃度は，反応液中の最終濃度として約 $25 \mathrm{r} / \mathrm{m} l$ を用い，それ以上の濃度条件ではおこな わなかった。これは，扣もに，高度精製した $\mathrm{Au}$ 抗原を大量に得る事が困難であることによる. 結果は前項に詳述したが，G A法，DFDNB 法， $\mathrm{CyCl}$ 法の 3 方法は, 生血球就よび固定血球のい ずれを用いても感作が成功しなかった．その原因 は，おそらく感作抗原の濃度によると考元られ る.すなわち，これら感作法の文献記載上に打け る至適感作抗原濃度は, 反応液中の最終濃度とし て, G A 法では, B S A $3 \sim 4 \mathrm{mg} / \mathrm{ml}$ (このとき 血球濃度 $1.5 \%$ ), DFDNB法では Human $\gamma$-globulin $28 \mathrm{mg} / \mathrm{m} l$ (血球濃度 $10 \%$ ), $\mathrm{CyCl}$ 法では, $1 \mathrm{mg} / \mathrm{ml}$ (血球濃度 $2.5 \%$ )である. 固定血球と生 血球では，ほぼ同一条件で感作をおこなっても， 感作成績は大きく異っていた。すなおち T A法や T D I C法では, 固定血球では高い血球凝集価を 示す感作血球を得るが，生血球では感作が成功し なかった. B D B法では, 固定血球では被検方法 のらち最も良い感作成績を得るのに, 生血球では 感作処理中の溶血がひどく感作血球の調製ができ なかった. $\mathrm{CrCl}_{3}$ 法では, 逆に, 生血球では感作が 効果的におこなわれたのに，固定血球では感作不 可能だった。このように生血球と固定血球の感作 成績が異なるのは，おもに固定処理により，血球 表面の荷電状態や血球表面の物質構造が变化 ${ }^{19,20)}$ するためであろう。なお，Polysaccharides や
Lipopolysaccharides などを抗原とする場合，結合 剤なしに感作血球を得られることが知られている が，約20\%の Lipid を含む ${ }^{21)}$ とされ Au 抗原で は，このような值接感作法は成功しなかった.

とくに化学的共有結合を感作機作とするいくつ かの感作方法を用いて感作血球を調製し，同一の 抗血清に対する血球凝集価を比較すると，ある種 の抗原に対する抗血清では同等であるのに，他の 抗原に対する抗血清では大きな差を示す場合が知 られており，その原因として結合試薬により抗原 決定基が破壊される可能性が 推論さされている Au抗原にはいくつかの抗原決定基が知られてい るが，感作方法によってはある抗原決定基が失活 する可能性が考えられる。この点を確認するた めに各抗原決定基の特異抗体に対して, 感作方法 を異にする感作血球を用いて血球凝集価を調べた が， T A 法， $\mathrm{CrCl}_{3}$ 法， B D B法拈よび T D I C 法のいずれも，ある抗原決定基の特異抗体に対す る血球凝集価が完全になくなることはなかった。 しかし，T D I C法では, 抗 Au 抗血清 Fおよび $\mathrm{S}$ に対する血球凝集価が相当高いのに, 他の感作 法にくらべて Anti-R, Anti-S ${ }_{2}$, Anti-Osに対する 血球凝集価が比較的低かったことから，これらの 抗原決定基が部分的に失活された可能性がある. 芳香族 isocyanate は，おすにタンパクのfree- $\mathrm{NH}_{2}$ 基と反応するとされる ${ }^{22)}$ が， AuR, $\mathrm{S}_{2}, \mathrm{Os}$ などの 抗原決定基の抗原活性には free- $\mathrm{NH}_{2}$ 基が関与し ていることが考えられる。一方，B D B法は， T D I C 法 と同様に共有結合を感作機作とする が，特異抗体に対する血球凝集価の傾向は，ほ葟 $\mathrm{T}$ A法や $\mathrm{CrCl}_{\mathbf{3}}$ 法と同じであった. Diazonium 化合物は, 括もにタンパクの Histidine 残基や Tyr-

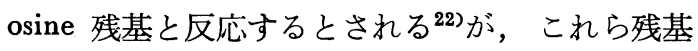
の化学变化は，Au 抗原の抗原性にあまり影響し ないのか子知れない. これらの知見から，抗原に 化学変化をもたらす感作法は native な抗原活性 を失活させたり， modify する可能性が考えられ るため，今後さらに発見されるかも知れない $\mathrm{Au}$ 抗原決定基の検索には， $\mathrm{T} \mathrm{A}$ 法や $\mathrm{CrCl}_{3}$ 法などの 感作血球を用いる方が望ましいと考えられる. 
感作血球の保存性に関しては，共有結合を機作と する B D B 法および T D I C 法の感作血球は $40^{\circ} \mathrm{C}$ 4 力月保存で, 全く力価低下を認めなかった。一 方, 吸着を感作機作とする $\mathrm{T} \mathrm{A}$ 法拈よび $\mathrm{CrCl}_{3}$ 法 においても，使用直前に血球を 1 回洗浄処理する ことにより，少なくとも，4 カ月間は調製直後の 力価を保っていた.

\section{むすび}

$\mathrm{Au}$ 抗原の感作血球調製のために 8 種類の感作 法を試みた。すなわち, タンニン酸法 (TA), bisdiazotized denzidine 法 (B D B), tolylene-2,4diisocyanate法 ( T D I C), difluorodinitrobenzene 法, tetraazotized O-dianisidine 法 (TOD), cyanulic chloride, glutaraldehyde, および塩化クロ ム法 $\left(\mathrm{CrCl}_{3}\right.$ 法)である. 感作液中の $\mathrm{Au}$ 抗原濃度 を, 約 $2.5 \mathrm{r} / \mathrm{m} l$ として感作すると, グルタール アルデヒド処理血球では T A, B D B , T D I C T O D, の各法により感作血球を得ることが可能 であり, 生血球では $\mathrm{CrCl}_{3}$ 法によってのみ感作 が可能であった. これらの感作法のうち最も感作 成績が優れていたのは B D B法であった。これら の感作法は，Au 抗原の抗原決定基を著しく不活 化することはなかった． B D B， T D I C， T A の各方法で調製した感作血球は， $4{ }^{\circ} \mathrm{C}$ に保存して 4 力月間は血球凝集価の低下を認めなかった.

本研究にあたり貴重なご助言をいただいた自治医大 免疫教室の真弓助教授, ご鞭摓いただいた内藤専務取締 役はじめ関係者各位に厚く感謝する。

\section{文献}

1) Boyden, S.V.: The adsorption of proteins on erythrocytes treated with tannic acid and subsequent hemagglutination by antiprotein sera. J. Exp. Med. 93: 107-120, 1951.

2) Stavitsky, A.B. \& Arquilla, E.R.: Micromethods for the study of proteins and antibodies III. Procedure and applications of hemagglutination and hemagglutination inhibition reactions with bis-diazotized benzidine and protein-conjugated red blood cells. $J$. Immunol. 74: 306-312, 1955.

3) Gyenes, L. \& Sehon, A.H.: The use of tolylene-2,4-diisocyanate as a coupling reagent in the passive hemagglutination reaction. Im- munochemistry 1: 43-48, 1964.

4) Ling, N.R.: The coupling of protein antigens to erythrocytes with difluorodinitrobenzene. Immunology 4: 49-54, 1961.

5) Onkelinx, E., Meuldermans, W., Joniau, M. \& Lontie, R.: Glutaraldehyde as a coupling reagent in passive hemagglutination. Immunology 16: 35-43, 1969.

6) Tokuda, G. \& Warrington, R.E.: Detection of Foot-and-mouse disease virus antibodies. Applied Microbiol. 20: 35-39, 1970.

7) Avrameas, S., Taudou, B. \& Chuilon, S.: Glutaraldehyde, cyanuric chloride and tetraazotized O-dianisidine as coupling reagents in the passive hemagglutination test. Immunochemistry 6: 67-76, 1969.

8) Johnson, H.M., Brenner, K. \& Hall, H.E.: The use of a water-soluble carbodiimide as a coupling reagent in the passive hemagglutination test. J. Immunol. 97: 791-796, 1966.

9) Gold, E.R. \& Fudenberg, H.H.: Chromic Chloride: A coupling reagent for passive hemagglutination reactions. J. Immunol. 99: 859866, 1967.

10) 今井光信, 高橋 隆, 真弓 忠, 大河内一雄 : 受身亦血球凝集反応に上るAu抗体の検出. 医学 の两印之, 78:759一760, 昭46.

11) Vyas, G.N. \& Shulman, N.R.: Hemagglutination assay for antigen and antibody associated with viral hepatitis. Science 170: 332-333, 1970.

12）滰本義一：固定ヒト $\mathrm{O}$ 型赤血球を用いた $\mathrm{Au}$ 抗原 感作血球の作製とそれによる抗 Au 抗体の検出 測定. 本誌, 19(4・5・6): 135-141, 1973.

13) 西岡久寿弥, 岡田英親: 免疫 9 生化学, 共立 出版, 東京, 昭44.102-107頁.

14) Gerin, J.L., Holland, P.V. \& Purcell, R.H.: Australia antigen: Large-scale purification from human serum and biochemical studies of its proteins. J. Virol. 7: 569-576, 1971.

15) Herbert, W.J.: Passive hemagglutination. Handbook of Immunology (Ed, by P.M. Weir), Blackwell Scientific Publication, Oxford, 1967. P. 720-744.

16) 木村義民：Microtitration と Hemagglutination. 免疫実験操作法 (免疫学会編) ,67-70頁.

17) 今井光信, 猪股みな子, 山下寬注か。オース トラリア抗原の抗原性, 臨床科学, $9: 347$ 一 352, 1973.

18）津田文男, 今井光信: 供血者に打けるオース トラリア抗原のSubgroup について. 第21回 日本輸血学会総会 (札㹸), 昭 48 .

19) Weiss, L., Zeigel, R., Jung, O.S. \& Bross, 
I.D.J.: Binding of positively charged particles to glutaraldehyde-fixed human erythrocytes. Exp. Cell Res. 70: 57-64, 1970.

20) Ling, N.R.: The attachment of proteins to aldehyde-tanned cells. Brit. J. Haemat. 7: 299-302, 1961.
21）高橋 隆，橋本 喬：オーストラリア抗原の 脂質組成. Proc. Jap. Conf. Biochem. Lipids 14 : 169-172, 1972.

22）赤堀四郎：蛋白質化学, II. 共立出版, 東京, 1954, 25一-47頁.

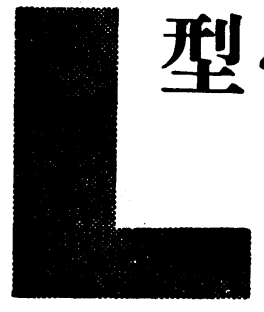

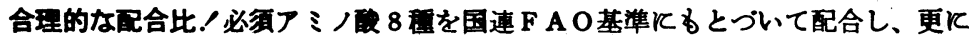

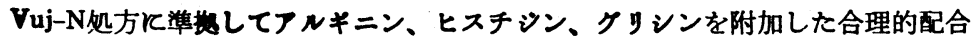
比です。

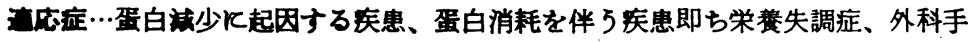

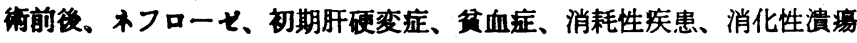

\begin{tabular}{|c|c|c|c|}
\hline & フミノ酸 & ソヘピゥト & 包 \\
\hline ヘ1・プレフミン注 & $12 \%$ & & $100 \mathrm{~m} \ell$ 2A $10 \mathrm{~A} 30 \mathrm{~A}$ \\
\hline ヘ1・ブレフミン注・10\%” & $10 \%$ & & $20 \mathrm{al} 10 \mathrm{~A} 50 \mathrm{~A} 100 \mathrm{ml} 2 \mathrm{~A} 10 \mathrm{~A} 30 \mathrm{~A} 200 \mathrm{ml} 2 \mathrm{~V}$ \\
\hline ヘ1・プレミン s 注 & $10 \%$ & $5 \%$ & $20 \mathrm{~m} l$ 10A50A $100 \mathrm{ml} 2 \mathrm{~A} 10 \mathrm{~A} 30 \mathrm{~A} 200 \mathrm{ml} 2 \mathrm{~V}$ \\
\hline 等張ハイ・プレフミン注 & $3 \%$ & & $100 \mathrm{ml} 2 \mathrm{~A} \quad 30 \mathrm{~A} \quad 500 \mathrm{ml} 1 \mathrm{~V}$ \\
\hline ヘイ・プレミン S T 注 & $3 \%$ & $5 \%$ & $500 \mathrm{ml} 1 \mathrm{~V}$ \\
\hline
\end{tabular}

